\title{
Synthesis and Characterization of a Linear, Two-Coordinate Pt(II) Ketimide Complex
}

\author{
Andrew W. Cook, ${ }^{a}$ Peter Hrobárik, ${ }^{* b}$ Peter L. Damon, ${ }^{a}$ Daniel Najera, ${ }^{a}$ Branislav Horváth, ${ }^{c}$ \\ Guang Wu, ${ }^{a}$ and Trevor W. Hayton ${ }^{* a}$ \\ ${ }^{a}$ Department of Chemistry and Biochemistry, University of California Santa Barbara, \\ Santa Barbara, CA 93106, USA \\ ${ }^{b}$ Department of Inorganic Chemistry, Faculty of Natural Sciences, Comenius University, \\ SK-84215 Bratislava, Slovakia
}

${ }^{c}$ Central NMR Laboratory, Faculty of Pharmacy, Comenius University, SK-83232 Bratislava, Slovakia 


\begin{abstract}
Herein we report the synthesis and characterization of a linear, two-coordinate Pt(II) ketimide complex, $\mathrm{Pt}\left(\mathrm{N}=\mathrm{C}^{\mathrm{t}} \mathrm{Bu}_{2}\right)_{2}(\mathbf{1})$, formed via reaction of $\mathrm{PtCl}_{2}(1,5-\mathrm{COD})$ with 2 equiv of $\mathrm{Li}\left(\mathrm{N}=\mathrm{C}^{\mathrm{t}} \mathrm{Bu}_{2}\right)$. Also generated in the reaction is the bimetallic complex, $\left[\left({ }^{t} \mathrm{Bu}_{2} \mathrm{C}=\mathrm{N}\right) \mathrm{Pt}(\mu-\mathrm{N}, \mathrm{C}-\right.$ $\left.\left.N=\mathrm{C}\left({ }^{\mathrm{t}} \mathrm{Bu}\right) \mathrm{C}(\mathrm{Me})_{2} \mathrm{CH}_{2}\right) \mathrm{Pt}\left(\mathrm{N}=\mathrm{C}^{\mathrm{t}} \mathrm{Bu}_{2}\right)\right](\mathbf{2})$. Both complexes $\mathbf{1}$ and $\mathbf{2}$ have been characterized by NMR spectroscopy and X-ray crystallography. Notably, complex 1 exhibits short Pt-N distances (av. $\mathrm{Pt}-\mathrm{N}=1.817 \AA)$ and an unusually deshielded ${ }^{195} \mathrm{Pt}$ chemical shift $(\delta \mathrm{Pt}=-629 \mathrm{ppm})$ with a large ${ }^{1} \mathrm{~J}\left({ }^{195} \mathrm{Pt},{ }^{14} \mathrm{~N}\right)$ coupling constant $(537 \mathrm{~Hz})$. These data, in combination with a detailed DFT electronic structure analysis, reveal the presence of highly covalent $\mathrm{Pt}=\mathrm{N}$ multiple bonds formed by a combination of $\sigma$-donation, $\pi$-donation, and $\pi$-backdonation.
\end{abstract}




\section{Introduction}

Two-coordinate complexes have come under increased scrutiny for their high reactivity and unique magnetic properties. ${ }^{1}$ Their low coordination number renders them highly reactive, owing to the ease of substrate access to the metal ion. Consequently, these materials are of interest for catalysis, small molecule activation, and as precursors to nanomaterials. ${ }^{2-6}$ These properties are perhaps best exemplified by the $\mathrm{M}\left(\mathrm{N}\left\{\mathrm{SiMe}_{3}\right\}_{2}\right)_{2}$-type complexes $(\mathrm{M}=\mathrm{Mn}, \mathrm{Fe}, \mathrm{Co}) .{ }^{1}$ For example, $\mathrm{Fe}\left(\mathrm{N}\left\{\mathrm{SiMe}_{3}\right\}_{2}\right)_{2}$ was found to be an effective pre-catalyst for both alkene hydrogenation and carbonyl hydrosilylation. ${ }^{7,8}$ With respect to magnetism, the highly anisotropic ligand field and unquenched orbital angular momentum extant in two-coordinate complexes leads to large magnetic moments and high barriers for magnetic reversal, which make these complexes promising single molecule magnets (SMMs). ${ }^{9-11}$ For example, the two-coordinate Fe(II) amide complex, $\mathrm{Fe}\left(\mathrm{N}^{\mathrm{t}} \mathrm{Bu}_{2}\right)_{2}$, features a high magnetic moment and a large internal magnetic field. ${ }^{12}$ Similar results are observed for $\left[\mathrm{Fe}\left(\mathrm{C}\left\{\mathrm{SiMe}_{3}\right\}\right)_{2}\right]^{0 /-} \cdot 9, \quad 13,14$ For the lanthanides, $\left[\left(\mathrm{Cp}^{\mathrm{ttt}}\right)_{2} \mathrm{Dy}\right]\left[\mathrm{B}\left(\mathrm{C}_{6} \mathrm{~F}_{5}\right)_{4}\right] \quad\left(\mathrm{Cp}^{\mathrm{ttt}} \quad=\quad\right.$ 1,2,4-tri(tert-butyl $)$ cyclopentadienyl $) \quad$ and $\left[\left(\mathrm{Cp}^{\mathrm{iPr} 5}\right) \mathrm{DyCp}^{*}\right]\left[\mathrm{B}\left(\mathrm{C}_{6} \mathrm{~F}_{5}\right)_{4}\right]$, which, while not truly two-coordinate, do feature large axial fields imposed by the trans arrangement of their two bulky Cp ligands and exhibit the highest energy barriers for magnetic reversal yet recorded. ${ }^{15-17}$ Similarly, $\left[\mathrm{Dy}\left(\mathrm{O}^{t} \mathrm{Bu}\right)_{2}(\mathrm{py})_{5}\right][\mathrm{BPh} 4$, which contains two axial alkoxide ligands, features a remarkably high barrier to magnetic relaxation. ${ }^{18}$

While these examples reveal the inherent promise of two-coordinate complexes in catalysis and for magnetic materials, further development in this area would benefit from the identification of new ligands that can enforce the desired 2-coordinate geometry. In this regard, the ketimide ligand, $\left[\mathrm{R}_{2} \mathrm{C}=\mathrm{N}\right]^{-}$, may be a suitable candidate. Like amides and alkoxides, ketimides are strong donors, and should be able to generate the required anisotropic ligand field for SMMs. And like amides 
and alkoxides, ketimides are easily tailored and can feature a broad range of steric profiles and donor abilities. ${ }^{19-22}$

Our research group has been exploring the chemistry of the ketimide ligand with a variety of transition metals. For example, we recently reported the syntheses of the homoleptic transition metal ketimides, $\mathrm{M}\left(\mathrm{N}=\mathrm{C}^{\mathrm{t}} \mathrm{Bu}_{2}\right)_{4}(\mathrm{M}=\mathrm{Fe}, \mathrm{Co}),{ }^{23,24}$ which both feature the relatively rare +4 formal oxidation state for these metals. ${ }^{23}$ They also both possess squashed tetrahedral geometries. ${ }^{24,25}$ These unusual properties are thought to be a consequence of the interplay between the strong $\pi$ donating and $\pi$-accepting abilities of the linear ketimide ligand. ${ }^{26}$ These strong donor properties suggested to us that ketimides could generate a strong axial ligand field in a two-coordinate complex.

Several other homoleptic $\mathrm{M}\left(\mathrm{N}=\mathrm{C}^{\mathrm{t}} \mathrm{Bu}_{2}\right)_{4}$-type complexes are also known, including examples containing $\mathrm{M}=\mathrm{Ti}, \mathrm{V}, \mathrm{Nb}, \mathrm{Ta}, \mathrm{Cr}, \mathrm{Mo}, \mathrm{W}$, and $\mathrm{Mn} \cdot{ }^{24-30}$ Homoleptic ketimide complexes are also known for copper, boron, aluminum, uranium, and cerium. ${ }^{31-35}$ In this context, the absence of a homoleptic group 10 ketimide is notable, especially given the foundational role that these elements have played in the development of organometallic chemistry. ${ }^{36}$ To rectify this oversight, we explored the reactivity of a series of $\mathrm{Pt}(\mathrm{II})$ salts with $\mathrm{Li}\left(\mathrm{N}=\mathrm{C}^{t} \mathrm{Bu}_{2}\right)$. Herein, we describe our first foray into group 10 ketimide chemistry, specifically the synthesis and characterization of a linear $\mathrm{Pt}(\mathrm{II})$ coordination complex, $\mathrm{Pt}\left(\mathrm{N}=\mathrm{C}^{\mathrm{t}} \mathrm{Bu}_{2}\right)_{2}$ (1), along with an analysis of its electronic structure and ${ }^{195} \mathrm{Pt}$ NMR spectrum using relativistic DFT calculations.

\section{Results and Discussion}

Synthesis and Characterization. The reaction of $\mathrm{PtCl}_{2}(1,5-\mathrm{COD})$ with 2 equiv of $\mathrm{Li}\left(\mathrm{N}=\mathrm{C}^{\mathrm{t}} \mathrm{Bu}_{2}\right)$ in THF results in immediate formation of yellow-orange solution, which gradually changes to red- 
brown over $90 \mathrm{~min}$. Work-up and crystallization from pentane results in the deposition of a mixture of small deep red-brown blocks of $\mathrm{Pt}\left(\mathrm{N}=\mathrm{C}^{\mathrm{t}} \mathrm{Bu}_{2}\right)_{2} \quad$ (1) and $\left[\left({ }^{\mathrm{t}} \mathrm{Bu} \mathrm{u}_{2} \mathrm{C}=\mathrm{N}\right) \mathrm{Pt}(\mu-\mathrm{N}, \mathrm{C}-\right.$ $\left.\left.N=\mathrm{C}\left({ }^{\mathrm{t}} \mathrm{Bu}\right) \mathrm{C}(\mathrm{Me})_{2} \mathrm{CH}_{2}\right) \mathrm{Pt}\left(\mathrm{N}=\mathrm{C}^{\mathrm{t}} \mathrm{Bu} \mathrm{u}_{2}\right)\right]$ (2) on the vial walls. ${ }^{1} \mathrm{H}$ NMR analysis of this mixture revealed the presence of $\mathbf{1}$ and $\mathbf{2}$ in an approximate 1:1 molar ratio (Scheme 1). Because of their similar solubilities, crystals of $\mathbf{1}$ and $\mathbf{2}$ always co-deposited, and because of their similar colors, they could not be manually separated. Thus, they were characterized as a mixture. They are both highly soluble in pentane, hexanes, $\mathrm{Et}_{2} \mathrm{O}$, benzene, toluene, and THF, and somewhat soluble in $\mathrm{MeCN}$. A few bright yellow crystals of a third product were also isolated from this reaction. Analysis by X-ray crystallography revealed these to be $\left[\mathrm{Pt}\left(\mathrm{N}=\mathrm{C}^{\mathrm{t}} \mathrm{Bu}_{2}\right)_{2}\left(\mu-\eta^{4}: \eta^{1}-\right.\right.$ $\left.\left.\mathrm{C}_{8} \mathrm{H}_{11}\right) \mathrm{Pt}\left(\mathrm{N}=\mathrm{C}^{\mathrm{t}} \mathrm{Bu}_{2}\right)(1,5-\mathrm{COD})\right]$ (4) (Figure $\mathrm{S} 16$ in $\mathrm{SI}$ ). This material was isolated in minute quantities and could not be further characterized. Attempts to perform the reaction of $\mathrm{Li}\left(\mathrm{N}=\mathrm{C}^{\mathrm{t}} \mathrm{Bu}_{2}\right)$ with other $\mathrm{Pt}(\mathrm{II})$ salts (such as $\mathrm{PtCl}_{2}$ or $\left.\mathrm{PtCl}_{2}(\mathrm{PhCN})_{2}\right)$ or with other ketimide precursors (e.g., $\mathrm{NaN}=\mathrm{C}^{t} \mathrm{Bu}_{2}$ ), in an effort to improve the chemoselectivity of the transformation, resulted in formation of intractable mixtures.

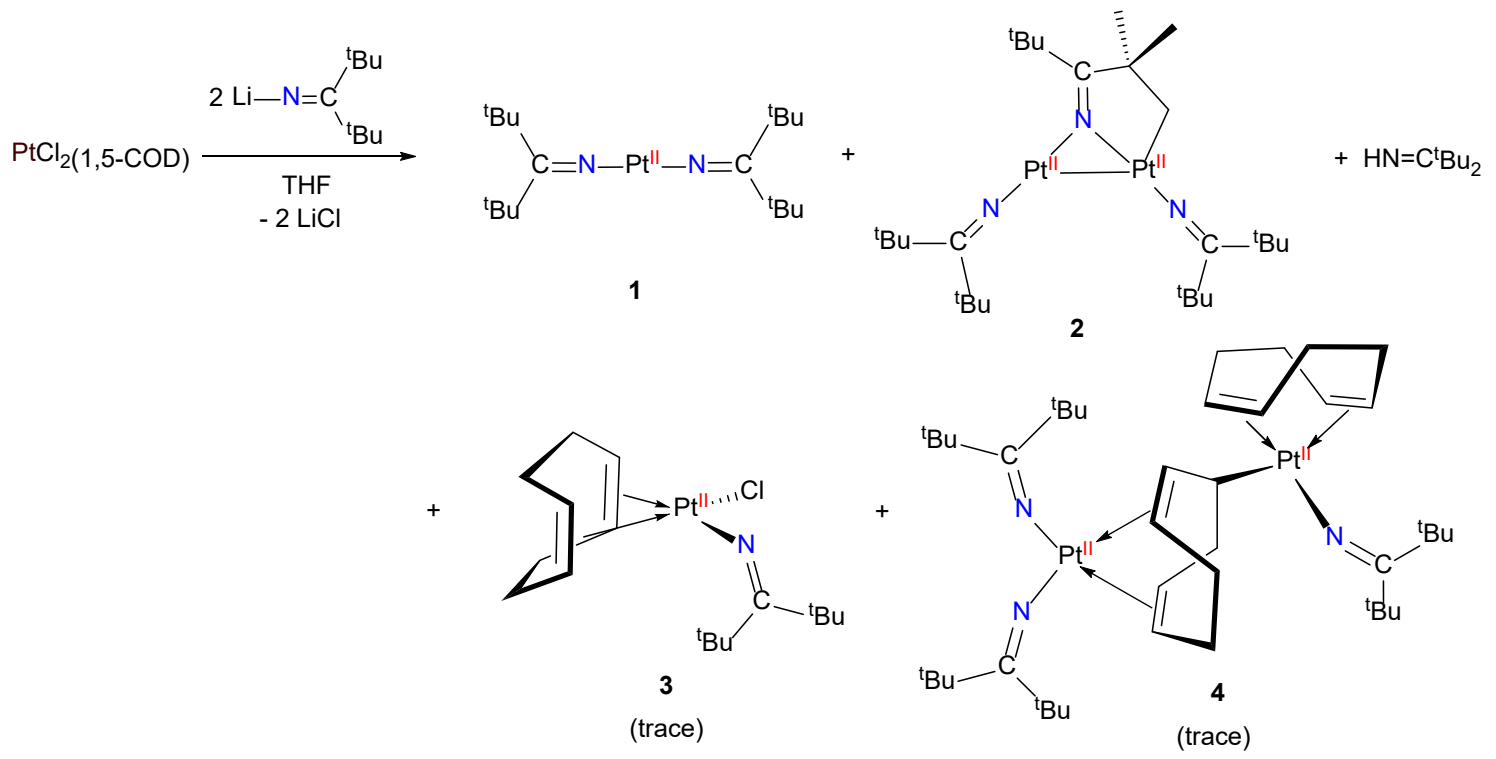

Scheme 1. Syntheses of complexes $1-4$ 
Complex 1 crystalizes in the triclinic space group $P$-1 (Figure 1). Each independent Pt center lies on a crystallographic center of symmetry; accordingly, the N-Pt-N angles of the two independent molecules in the unit cell are both $180^{\circ}$. The Pt-N bond distances in 1 are exceptionally short (1.815(4) and 1.818(4) Å). According to a search of the Cambridge Structural Database,${ }^{37}$ these are the shortest Pt-N distances reported thus far. For comparison, the Pt(II) amides, cis- $\mathrm{Pt}(\mathrm{Cl})\left(\mathrm{NPh}_{2}\right)\left(\mathrm{PEt}_{3}\right)_{2}$ and trans- $\mathrm{Pt}(\mathrm{H})(\mathrm{NHPh})\left(\mathrm{PEt}_{3}\right)_{2}$, feature much longer Pt-N bond lengths of $2.09(2) \AA$ and $2.125(5) \AA$, respectively, ${ }^{38-41}$ while the $\operatorname{Pt}(\mathrm{II})$ ketimide, $\left[\mathrm{Pt}(\mathrm{bpy}) \mathrm{Me}(\mathrm{N}=\mathrm{CMe}\{\mathrm{C}(\mathrm{C}(\mathrm{Me})=\mathrm{O})(=\mathrm{C}(\mathrm{Me}) \mathrm{OH}\})]\right.$, features a Pt-N bond length of 2.01(2) $\AA .{ }^{42}$ The $\mathrm{N}=\mathrm{C}$ bond lengths of the ketimide ligands in $\mathbf{1}$ (1.256(6), 1.258(2) $\AA$ ) are typical of carbonnitrogen distances in other ketimide complexes, ${ }^{24-26,43}$ and the Pt-N-C bond angles in 1 (179.7(4), $\left.178.4(4)^{\circ}\right)$ are consistent with sp hybridization of the $\mathrm{N}$ atom. ${ }^{24-26,43}$ Finally, we note that the two ketimide ligands in $\mathbf{1}$ are co-planar, suggesting that the nitrogen lone pairs on the two [ $\left.{ }^{\mathrm{t}} \mathrm{Bu}_{2} \mathrm{C}=\mathrm{N}\right]^{-}$ ligands interact with the same $\mathrm{Pt}(5 \mathrm{~d})$ orbital (see further discussion below). 


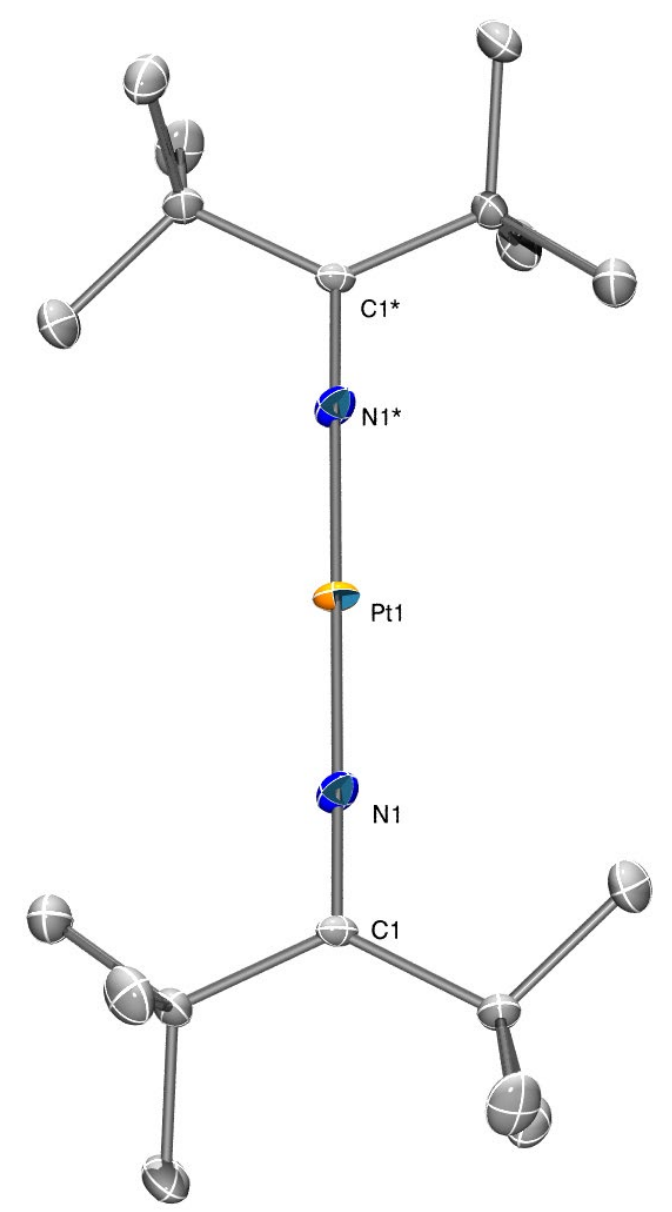

Figure 1. ORTEP diagram of one independent molecule of 1 shown with $50 \%$ probability ellipsoids. Hydrogen atoms and a second molecule of $\mathbf{1}$ are omitted for clarity. Selected bond distances $(\AA)$ and angles $\left(^{\circ}\right)$ : Pt1-N1 = 1.815(4), Pt2-N2 = 1.818(4), N1-C1 = 1.256(6), N2-C10= 1.258(2), N1-Pt1-N1* = 180, N2-Pt2-N2* = 180, C1-N1-Pt1 = 179.7(4), C10-N2-Pt2 = 178.4(4).

Complex 2, which was isolated along with $\mathbf{1}$, crystallizes in the monoclinic space group P $2{ }_{1} / n$ (Figure 2). It features two Pt(II) centers, each ligated by a terminal ketimide ligand, and each bridged by a ketimide ligand that has also been deprotonated at a methyl carbon. The nitrogen of the modified ketimide ligand is ligated to both Pt centers, while its methylene group is only ligated to Pt2. Similar to 1, all three ketimide ligands in 2 are co-planar and the N-Pt-N angles (166.1(4) and $\left.170.6(3)^{\circ}\right)$ approach linearity. The Pt-N distances for the terminal ketimide ligands $(1.825(8)$ 
and $1.85(1) \AA$ ) are similar to those observed in $\mathbf{1}$, while their Pt-N-C angles (175.8(8) and $\left.164.7(8)^{\circ}\right)$ are close to $180^{\circ}$. Both features are suggestive of a strong degree of $\pi$-donation and/or $\pi$-backdonation from/to the ketimide ligand. The Pt-Pt distance (2.5951(6) $\AA$ ) is much shorter than those reported for other platinum(II) complexes with bridging amido ligands, ${ }^{44,45}$ but is in line with those seen in Pt(II) acetate. ${ }^{46}$ Finally, the Pt-C distance (2.08(1) $\left.\AA\right)$ is similar to those of other structurally characterized Pt(II) complexes with C-H activated ${ }^{\text {tBu groups. }}{ }^{47-50}$

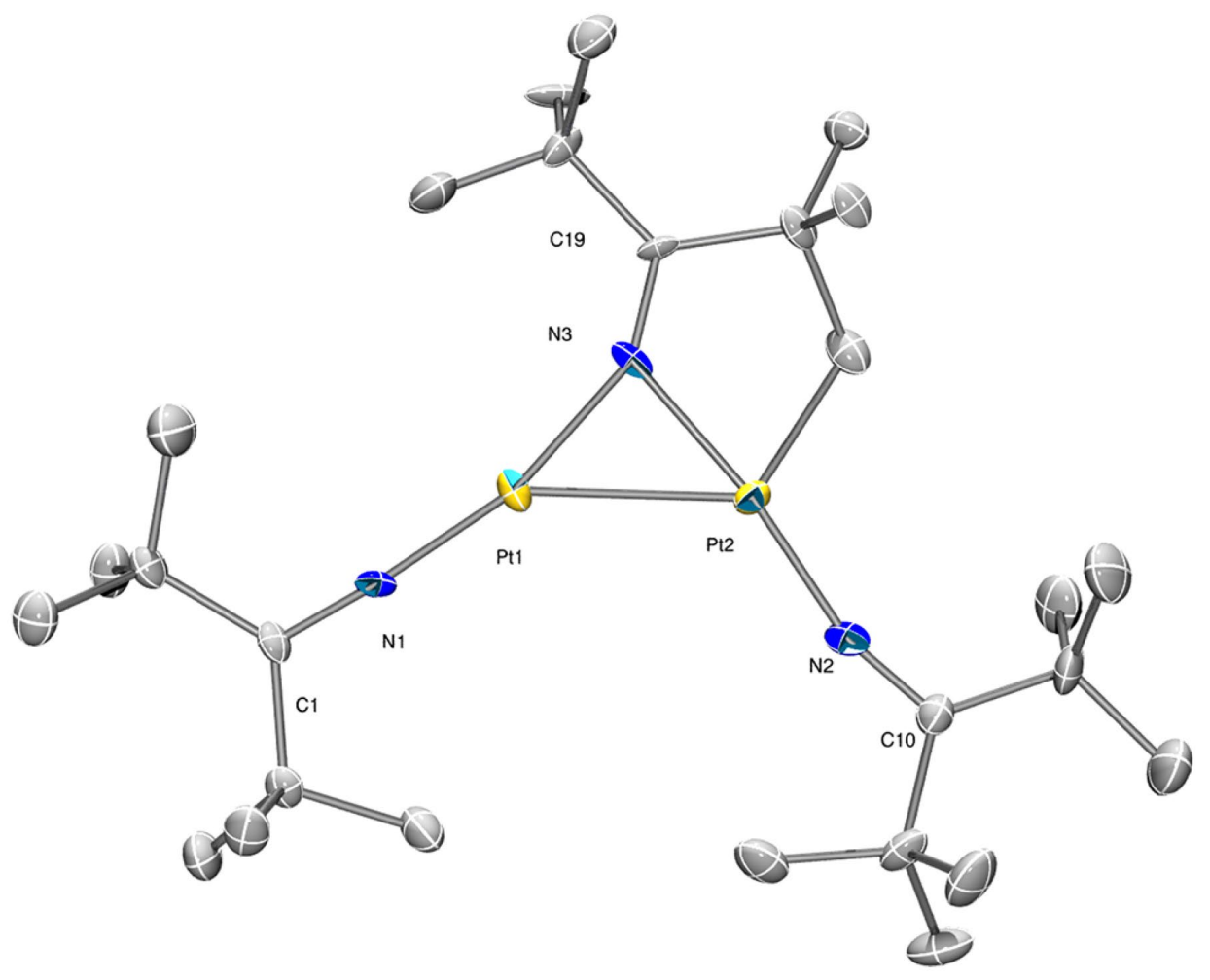

Figure 2. ORTEP diagram of $\mathbf{2}$ shown with $50 \%$ probability ellipsoids. Hydrogen atoms are omitted for clarity. Selected bond distances $(\AA)$ and angles $\left({ }^{\circ}\right)$ : Pt1-N1 $=1.825(8)$, Pt2-N2 $=$ 1.85(1), Pt1-Pt2 = 2.5951(6), Pt1-N3 = 1.934(7), Pt2-N3 = 1.989(9), Pt2-C27 = 2.08(1), N1-Pt1$\mathrm{N} 3=166.1(4), \mathrm{N} 2-\mathrm{Pt} 2-\mathrm{N} 3=170.6(3), \mathrm{C} 1-\mathrm{N} 1-\mathrm{Pt} 1=175.8(8), \mathrm{C} 10-\mathrm{N} 2-\mathrm{Pt} 2=164.7(8), \mathrm{C} 19-\mathrm{N} 3-$ Pt1 $=151.6(8)$, C19-N3-Pt2 = 125.4(7). 
While we were unable to isolate pure samples of $\mathbf{1}$ or $\mathbf{2}$ (their crystals always co-deposited; see Experimental Section), we were able to fully assign the ${ }^{1} \mathrm{H}$ NMR spectrum of the combined solids. The spectrum in $\mathrm{C}_{6} \mathrm{D}_{6}$ features of a sharp singlet at $1.11 \mathrm{ppm}$, which is assignable to 1 (Figures S5 and S6). Additionally, there are 3 singlets, at 1.46, 1.30, and $1.28 \mathrm{ppm}$, each integrating for 9 protons, and one singlet at $1.22 \mathrm{ppm}$, integrating for 18 protons, which are assignable to the 5 magnetically inequivalent ${ }^{\mathrm{B}} \mathrm{Bu}$ groups (with two overlapping) of $\mathbf{2}$. Additionally, the spectrum features a singlet at $1.18 \mathrm{ppm}$, which integrates for 6 protons, and a singlet at $3.25 \mathrm{ppm}$, which integrates for 2 protons (and features Pt satellites with ${ }^{2} J_{\mathrm{PtH}}=88 \mathrm{~Hz}$ ). An ESI-MS of the isolated crystals (dissolved in THF) features a signal at $m / z 476.2674$ (Figures S11 and S12 in SI), which corresponds to the $[1+\mathrm{H}]^{+}$ion (calcd $m / z$ 476.2645). This spectrum features a second prominent signal at $m / z 810.3602$ (Figure $\mathrm{S} 13$ in SI), which corresponds to $[2+\mathrm{H}]^{+}(\mathrm{calcd} m / z$ 810.3633).

Moreover, for a mixture of $\mathbf{1}$ and $\mathbf{2}$ that was slightly enriched with $\mathbf{1}$, we detected in $\mathrm{C}_{6} \mathrm{D}_{6}$ at $25{ }^{\circ} \mathrm{C}$ a ${ }^{195} \mathrm{Pt}$ NMR resonance at $-663 \mathrm{ppm}$ that is assignable to 1 (Figure $\mathrm{S} 10 \mathrm{in} \mathrm{SI} ;{ }^{195} \mathrm{Pt}$ NMR shifts in ppm vs. $\left.\mathrm{Na}_{2} \mathrm{PtCl}_{6}(\mathrm{aq})\right)$. Upon increasing the temperature to $50{ }^{\circ} \mathrm{C}$, the signal shifted downfield $\left(\delta_{\mathrm{Pt}}=-629 \mathrm{ppm}\right)$ and became a well-resolved quintet due to couplings with two equivalent ${ }^{14} \mathrm{~N}$ nuclei $(I=1)$, with ${ }^{1} J\left({ }^{195} \mathrm{Pt},{ }^{14} \mathrm{~N}\right)=537 \mathrm{~Hz}$ (Figure 3). The ${ }^{195} \mathrm{Pt}$ nucleus in $\mathbf{1}$ is remarkably deshielded as compared to other Pt(II) complexes with nitrogen-based ligands, which normally feature $\delta_{\mathrm{Pt}}$ within the range -2700 to $-1700 \mathrm{ppm}$ (cf. Table S7 in SI). In addition, the ${ }^{1} J\left({ }^{195} \mathrm{Pt},{ }^{14} \mathrm{~N}\right)$ value is the largest coupling constant reported to date for a Pt-N bond, consistent with the short distance and multiple bond character in $\mathbf{1}$. The assignment of these NMR parameters to complex 1 was confirmed by relativistic two-component DFT calculations including spin-orbit coupling (2c-ZORA(SO)/PBE/QZ4P), which predict $\delta_{\mathrm{Pt}}=-601 \mathrm{ppm}$ and ${ }^{1} J_{\mathrm{Pt}, \mathrm{N}}=576 \mathrm{~Hz} \cdot{ }^{51}$ For 
complex 2, the ${ }^{195} \mathrm{Pt}$ NMR shifts are predicted to appear at -2054 and $-2928 \mathrm{ppm}$, but no signal within the range -6000 to -1000 ppm was detected in our ${ }^{195} \mathrm{Pt}$ NMR experiments. ${ }^{52}$

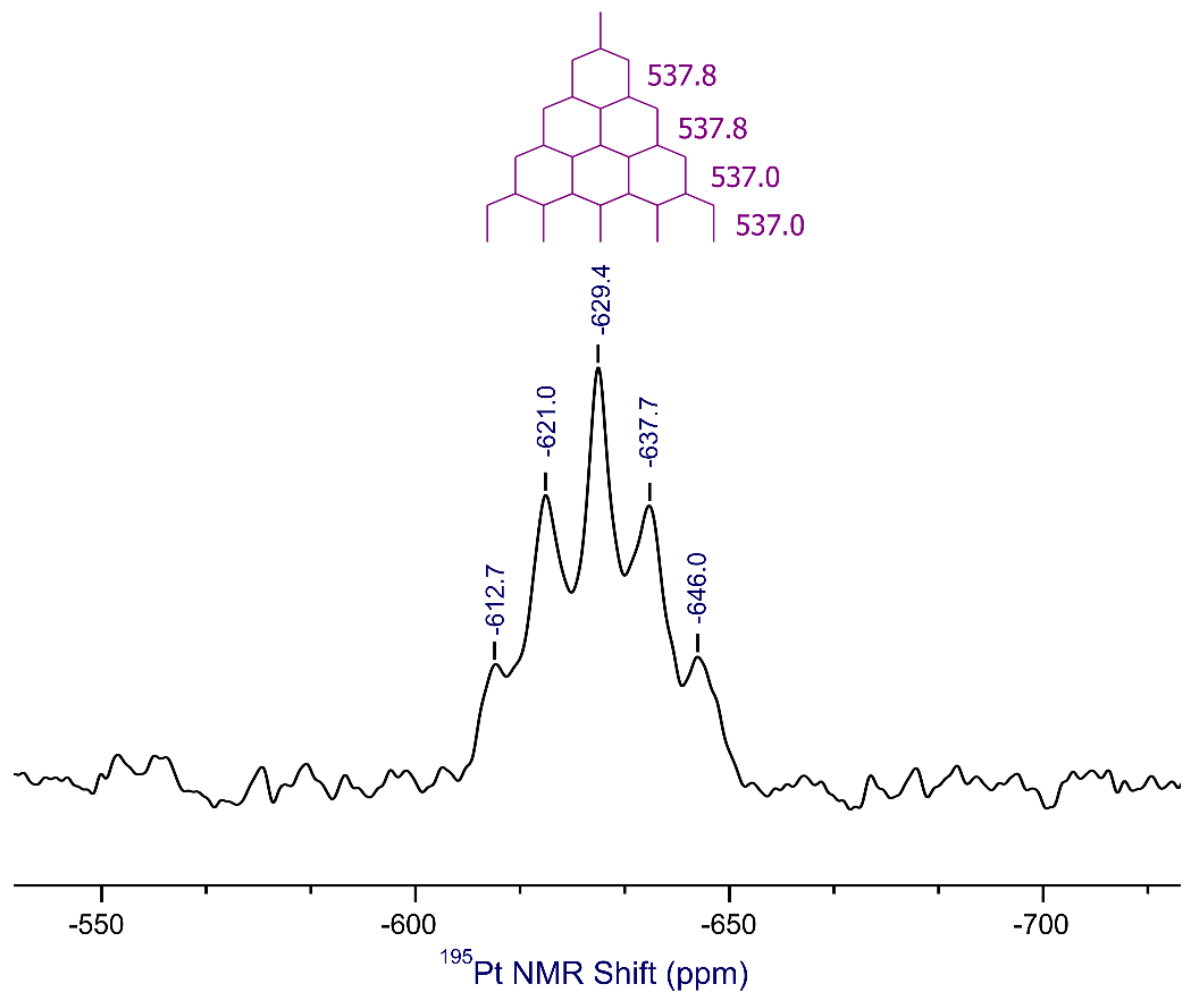

Figure 3. Partial ${ }^{195} \mathrm{Pt}$ NMR spectrum of a mixture of $\mathbf{1}$ and $\mathbf{2}$ in $\mathrm{C}_{6} \mathrm{D}_{6}$, recorded at $50{ }^{\circ} \mathrm{C}$.

To better understand the formation of $\mathbf{1}$ and $\mathbf{2}$, and identify the origin of the poor chemoselectivity, we monitored the reaction of $\mathrm{PtCl}_{2}(1,5-\mathrm{COD})$ with 2 equiv of $\mathrm{Li}\left(\mathrm{N}=\mathrm{C}^{\mathrm{t}} \mathrm{Bu}_{2}\right)$ by ${ }^{1} \mathrm{H}$ NMR spectroscopy. A ${ }^{1} \mathrm{H}$ NMR spectrum of an aliquot of the crude reaction mixture, taken after 20 min of reaction time, reveals the presence of the complexes $\mathbf{1 , 2}$, and the mono(ketimide) complex, $\left[\mathrm{Pt}(1,5-\mathrm{COD})\left(\mathrm{N}=\mathrm{C}^{t} \mathrm{Bu}_{2}\right) \mathrm{Cl}\right](3)$, in an approximately 1:2:10 ratio, respectively (Figures $\mathrm{S} 1$ and $\mathrm{S} 2$ in SI). After $90 \mathrm{~min}$ of reaction time, a ${ }^{1} \mathrm{H}$ NMR spectrum of an aliquot reveals the presence of the complexes $\mathbf{1}, \mathbf{2}$, and $\mathbf{3}$ in an approximately 1:1:1 ratio, respectively (Figures S3 and $\mathrm{S} 4$ in SI). Also present in the 90 min spectrum is a small amount of $\mathrm{HN}=\mathrm{C}^{\mathrm{t}} \mathrm{Bu}_{2}$, as well as signals that that we have tentatively assigned to dinuclear Pt complex 4, $\left[\mathrm{Pt}\left(\mathrm{N}=\mathrm{C}^{\mathrm{t}} \mathrm{Bu}\right)_{2}\left(\mu-\eta^{4}: \eta^{1}-\right.\right.$ 
$\left.\left.\mathrm{C}_{8} \mathrm{H}_{11}\right) \mathrm{Pt}\left(\mathrm{N}=\mathrm{C}^{\mathrm{t}} \mathrm{Bu}_{2}\right)(1,5-\mathrm{COD})\right]$. According to the ${ }^{1} \mathrm{H}$ NMR spectrum, 4 is not formed in significant quantities, but its presence, along with the presence of small amounts of $\mathbf{3}$, help rationalize the relatively low yields of $\mathbf{1}$ and $\mathbf{2}$.

Complex 3 can be independently synthesized by reaction of $\mathrm{PtCl}_{2}(1,5-\mathrm{COD})$ with 1 equiv of $\mathrm{Li}\left(\mathrm{N}=\mathrm{C}^{t} \mathrm{Bu}_{2}\right)$ in $\mathrm{THF}(\mathrm{Scheme} 2)$. When generated in this fashion it can be isolated as an orange powder in $46 \%$ yield. Complex 3 has been characterized by X-ray crystallography and by ${ }^{1} \mathrm{H}$ and ${ }^{13} \mathrm{C}\left\{{ }^{1} \mathrm{H}\right\}$ NMR spectroscopy (Figures S7, S8, and S15 in SI). In the solid state, it features a Pt-N

bond length of 1.961(4) $\AA$, which is notably longer than those of $\mathbf{1}$, and is suggestive of a significantly lesser degree of $\pi$-donation and $\pi$-backdonation between the Pt center and ketimide ligand (Figure S15 in SI). Consistent with this hypothesis, the Pt-N-C angle in 3 (143.8(4) deviates significantly from linearity.

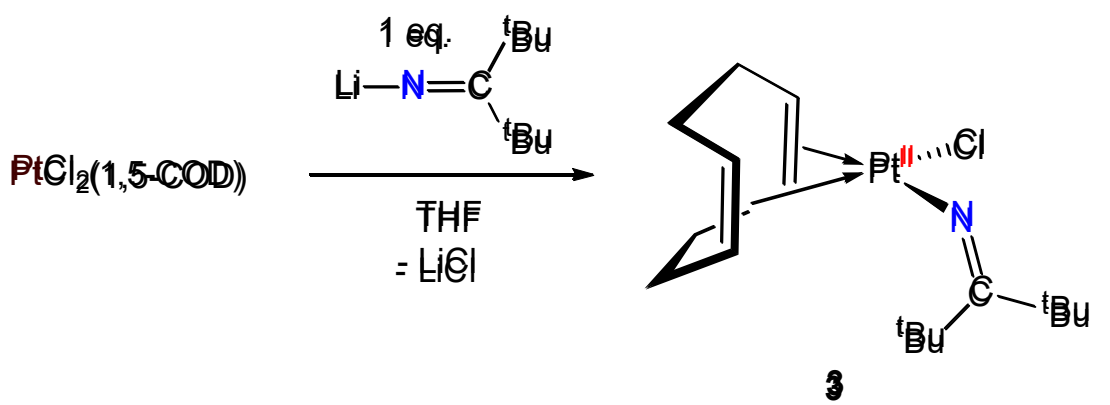

Scheme 2. Synthesis of complex 3.

We also explored the suitability of $\mathbf{3}$ as a precursor to complexes $\mathbf{1}$ and $\mathbf{2}$. Thus, reaction of $\mathbf{3}$ with 1 equiv of $\mathrm{Li}\left(\mathrm{N}=\mathrm{C}^{\mathrm{t}} \mathrm{Bu}_{2}\right)$ in THF results formation of both $\mathbf{1}$ and $\mathbf{2}$ in an approximately 1:1 ratio, according to a ${ }^{1} \mathrm{H}$ NMR spectrum of the crude reaction mixture (Figure S9 in SI). Several other minor resonances are also present in the reaction mixture, which we have tentatively assigned to complex 4. A small amount of $\mathrm{HN}=\mathrm{C}^{t} \mathrm{Bu}_{2}$ is also present in the sample. Given that this route did not appear to offer any advantages over the initial method of preparation, it was not pursued further. 
Computational Analysis. In an effort to explain the unique structural features of the twocoordinate Pt ketimide complex, we performed a computational bonding analysis of $\mathbf{1}$ and its truncated model complex, $\mathrm{Pt}\left(\mathrm{N}=\mathrm{CH}_{2}\right)_{2}\left(\mathbf{1}^{\prime}\right)$. DFT calculations accurately reproduce the short $\mathrm{Pt}-\mathrm{N}$ bond lengths, linear coordination geometry, and co-planar arrangement of ketimide ligands in both 1 and $\mathbf{1}^{\prime}$ (Table 1). These features remain virtually unaffected upon replacing tert-butyl groups in the ketimide ligand with hydrogen atoms, demonstrating the minimal role of attractive London dispersion forces and/or steric repulsion between bulky alkyl groups on the structure.

A molecular orbital (MO) diagram for $\mathbf{1}^{\prime}$ in its singlet $(S=0)$ ground-state is depicted in Figure 4 (selected frontier MOs of $\mathbf{1}$ are given in Figure S17 in SI and give qualitatively the same picture as presented here). As expected, the metal-based atomic orbitals $d_{x y}$ (HOMO-3) and $d_{x 2-y 2}$ (HOMO-4) are basically non-bonding (they do not interact with the orbitals of the $\mathrm{R}_{2} \mathrm{C}=\mathrm{N}$ fragments), the HOMO is predominantly metal-based $5 \mathrm{~d}_{\mathrm{z} 2}-6 \mathrm{~s}$ in character, and the LUMO involves the $5 \mathrm{~d}_{\mathrm{yz}}$ atomic orbital and has a clear $\pi^{*}(\mathrm{Pt}-\mathrm{N})$ antibonding character. While it is sometimes a challenge to classify the nature of a bonding interaction from the canonical MOs, ${ }^{53}$ the HOMO-5 $\left(\mathrm{d}_{\mathrm{yz}}\right)$ and HOMO-7 $\left(\mathrm{d}_{\mathrm{xz}}\right)$ orbitals are best described as the Pt-N $\pi$ donation and Pt-N $\pi$ backdonation interactions, respectively. This assessment is confirmed by inspection of the corresponding Naturally Localized Molecular Orbitals (NLMOs) ${ }^{54}$ (Figure S20) and Adaptive Natural Density Partitioning (AdNDP) ${ }^{55}$ analysis (Figure 5), which provide a chemically more intuitive description of bonding, exploiting the concept of Lewis structures with shared pairs of electrons between adjacent atoms (see discussion below). ${ }^{53}$ In particular, the NLMO Pt-N $\pi$-bonds (shown in Figure S20) are formed by linear combinations of HOMO-1 and HOMO-5, along with lesser amounts of HOMO-9 and HOMO-10 (Figure 4), while the Pt-N $\pi$-backbonding interaction 
(shown in Figure S20) is composed principally of HOMO-7 with a small admixture of HOMO-2 (Figure 4).

Table 1. Atomic NPA charges, NLMO analysis of the M-N bonding, and QTAIM delocalization indices, DI(M-N), as a measure of the M-N bond covalency, in a series of two-coordinate group $10 \mathrm{M}\left(\mathrm{N}=\mathrm{CR}_{2}\right)_{2}\left(\mathrm{R}=\mathrm{H},{ }^{\mathrm{t}} \mathrm{Bu}\right)$ ketimide complexes ${ }^{a, b}$

\begin{tabular}{|c|c|c|c|c|c|c|c|c|c|c|c|}
\hline \multirow[t]{2}{*}{ Complex } & \multirow{2}{*}{$\begin{array}{c}d(\mathrm{M}-\mathrm{N}) \\
{[\AA]}\end{array}$} & \multicolumn{2}{|c|}{ NPA charges } & \multicolumn{7}{|c|}{ NLMO analysis of the M-N bonds } & \multirow{2}{*}{$\begin{array}{l}\text { QTAIM } \\
\text { DI(M-N) }\end{array}$} \\
\hline & & $\mathrm{q}(\mathrm{M})$ & $q(N)$ & type & $\% \mathrm{M}$ & $\% \mathrm{M}(\mathrm{s})$ & $\% \mathrm{M}(\mathrm{d})$ & $\% \mathrm{~N}$ & $\% \mathrm{~N}(\mathrm{~s})$ & $\% \mathrm{~N}(\mathrm{p})$ & \\
\hline \multirow[t]{3}{*}{$\operatorname{Pt}\left(\mathrm{N}=\mathrm{CH}_{2}\right)_{2}$} & 1.797 & 0.452 & -0.481 & $\sigma(\mathrm{M} \leftarrow \mathrm{N})$ & 15.6 & 71 & 29 & 83.3 & 52 & 48 & 1.514 \\
\hline & & & & $\pi(\mathrm{M} \leftarrow \mathrm{N})$ & 29.0 & & 100 & 64.5 & & 100 & \\
\hline & & & & $\pi(\mathrm{N} \leftarrow \mathrm{M} \rightarrow \mathrm{N})$ & 69.5 & & 100 & 14.5 & & 100 & \\
\hline \multirow[t]{3}{*}{$\operatorname{Pt}\left(\mathrm{N}=\mathrm{C}^{\mathrm{t}} \mathrm{Bu}_{2}\right)_{2}$} & 1.803 & 0.433 & -0.553 & $\sigma(\mathrm{M} \leftarrow \mathrm{N})$ & 15.3 & 71 & 29 & 83.2 & 48 & 52 & 1.463 \\
\hline & & & & $\pi(\mathrm{M} \leftarrow \mathrm{N})$ & 29.3 & & 100 & 64.0 & & 100 & \\
\hline & & & & $\pi(\mathrm{N} \leftarrow \mathrm{M} \rightarrow \mathrm{N})$ & 70.8 & & 100 & 13.9 & & 100 & \\
\hline \multirow[t]{3}{*}{$\mathbf{P d}\left(\mathrm{N}=\mathrm{C}^{\mathrm{t}} \mathrm{Bu}_{2}\right)_{2}$} & 1.824 & 0.395 & -0.507 & $\sigma(\mathrm{M} \leftarrow \mathrm{N})$ & 11.2 & 82 & 17 & 87.5 & 48 & 52 & 1.295 \\
\hline & & & & $\pi(\mathrm{M} \leftarrow \mathrm{N})$ & 31.2 & & 100 & 61.3 & & 100 & \\
\hline & & & & $\pi(\mathrm{N} \leftarrow \mathrm{M} \rightarrow \mathrm{N})$ & 78.4 & & 100 & 10.2 & & 100 & \\
\hline \multirow[t]{3}{*}{$\mathbf{N i}\left(\mathrm{N}=\mathrm{C}^{\mathrm{t}} \mathrm{Bu}_{2}\right)_{2}$} & 1.683 & 0.655 & -0.619 & $\sigma(\mathrm{M} \leftarrow \mathrm{N})$ & 9.0 & 90 & 10 & 89.6 & 47 & 53 & 1.289 \\
\hline & & & & $\pi(\mathrm{M} \leftarrow \mathrm{N})$ & 26.4 & & 100 & 67.0 & & 100 & \\
\hline & & & & $\pi(\mathrm{N} \leftarrow \mathrm{M} \rightarrow \mathrm{N})$ & 80.3 & & 100 & 9.3 & & 100 & \\
\hline
\end{tabular}

${ }^{a} \mathrm{PBE} 0-\mathrm{D} 3(\mathrm{BJ}) / \mathrm{ECP} / \mathrm{def} 2-\mathrm{TZVP}$ results (see Computational details); the metal atom (M) bound to nitrogen is indicated in bold; ${ }^{b} \pi(\mathrm{N} \leftarrow \mathrm{M} \rightarrow \mathrm{N})$ corresponds to a $\pi$-backdonation from the metal dorbital to $\pi^{*}(\mathrm{~N}=\mathrm{C})$ antibonding MOs.

On the basis of ligand-field theory, ${ }^{56}$ one would expect the LUMO of a linear, $16 \mathrm{e}^{-}$complex to be predominately $\mathrm{d}_{\mathrm{z} 2}$ in character, which is not the ordering observed for $\mathbf{1}^{\prime}$ or $\mathbf{1}$. This discrepancy 
can be rationalized by the extensive ligand-induced $5 \mathrm{~d}-6 \mathrm{~s}$ hybridization, which lowers the energy of the $\mathrm{d}_{\sigma}$ manifold, and by the strong metal $\left(\mathrm{d}_{\pi}\right)$-ligand $(\pi)$ interactions at the short M-L distances, which increases the antibonding $\mathrm{M}\left(\mathrm{d}_{\pi, \mathrm{g}}\right)-\mathrm{L}\left(\mathrm{p}_{\pi}\right)^{*}$ level. A notable $5 \mathrm{~d}-6 \mathrm{~s}$ hybridization is also observed for a $\mathrm{Pt}$ atom (or $\mathrm{Pt}^{2+}$ ion) placed between two negative point charges $(q=-1.0 e)$ separated by ca. $4 \AA$ (Figure 4, left). The d-s hybridization shifts the charge from the axial lobes of the $5 \mathrm{~d}_{\mathrm{z} 2}$ orbital into its toroidal ring and reduces the Pauli repulsion between $\operatorname{Pt}\left(5 \mathrm{~d}_{\mathrm{z} 2}\right)$ and ligand $\sigma$-type $\left(\mathrm{ag}_{\mathrm{g}}\right)$ orbitals. A similar d-electron distribution in the ground-state of two-coordinate complexes (accompanied with a d-s hybridization) was also found in a series of $3 \mathrm{~d}$ metal dihalogenides and in a series of recently published 2-coordinate iron complexes containing bulky amide or tris(trimethylsilyl)methyl ligands. ${ }^{9,12,13,57,58}$ 


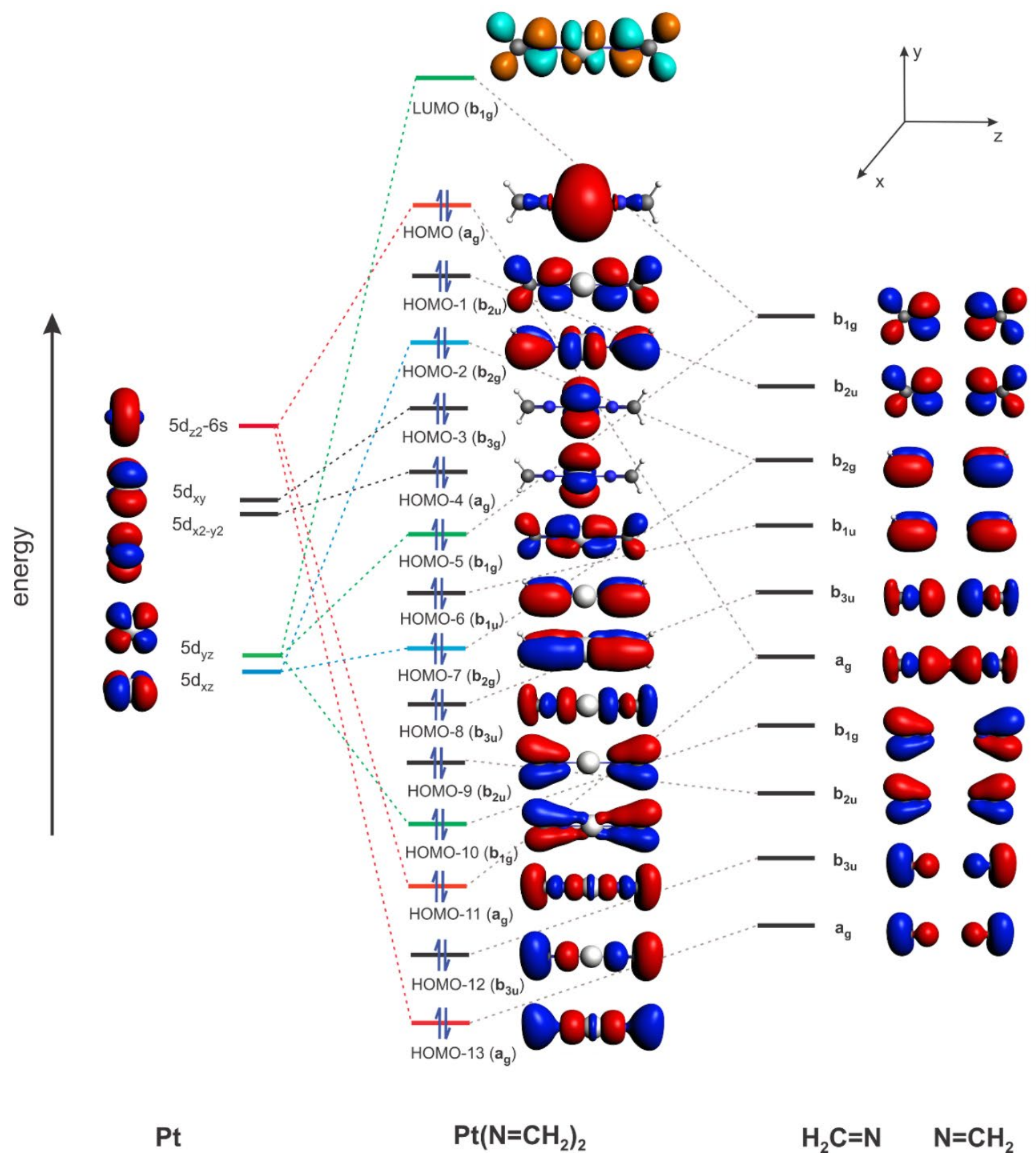

Figure 4. Schematic MO diagram for complex 1' (for the sake of clarity, given MO levels are aligned based on their energies only qualitatively). Canonical MOs are depicted as isosurface plots ( $\pm 0.03 \mathrm{au}$ ). Symmetry labels are for $D_{2 h}$ point group. The left side of the figure shown the splitting of the $\mathrm{d}$ orbital manifold and the $\operatorname{Pt}\left(5 \mathrm{~d}_{\mathrm{z} 2}\right) / \operatorname{Pt}(6 \mathrm{~s})$ hybridization that occurs upon interaction of the Pt atom with two negative point charges positioned in a linear fashion with respect to the metal and each separated by $2 \AA$ from the Pt center. 

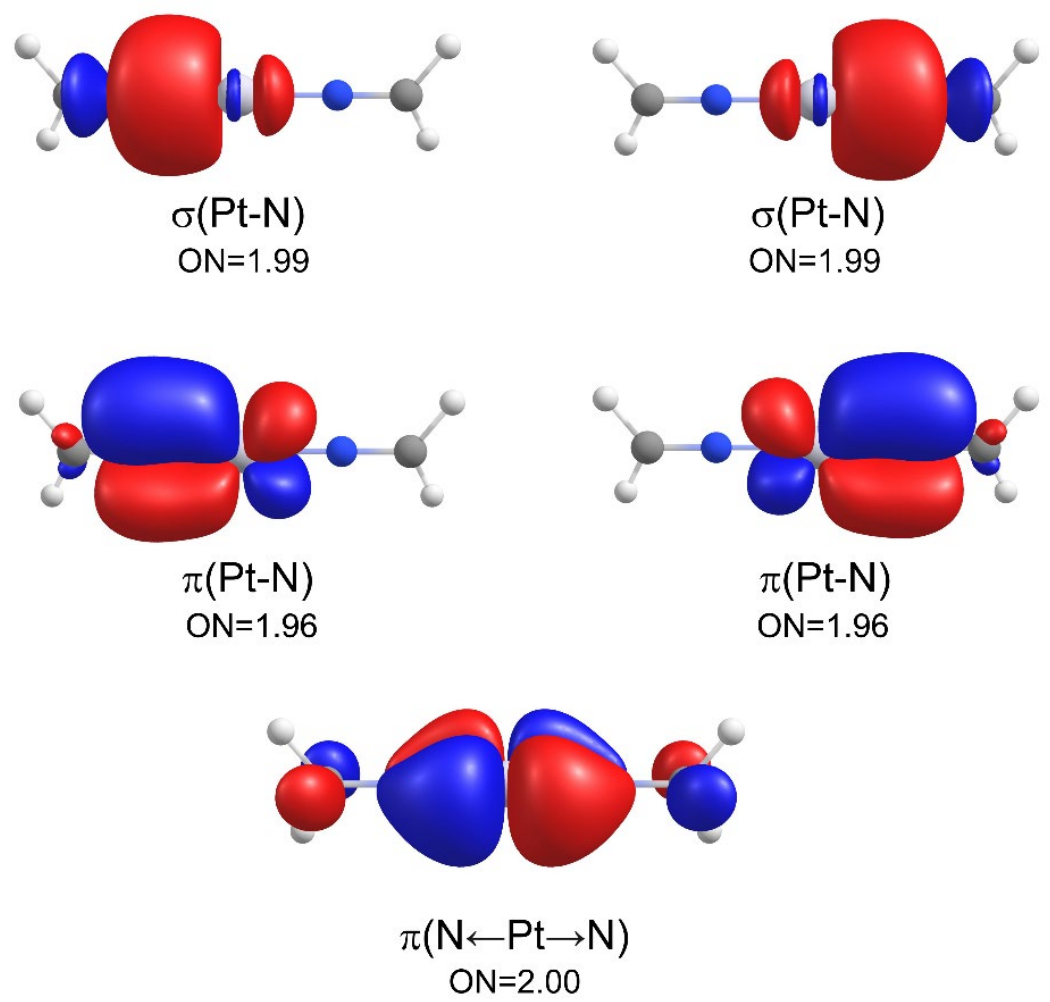

Figure 5. Localized AdNDP orbitals corresponding to Pt-N interaction in 1'. ON stands for occupation number. See also Figure S20 in SI for corresponding NLMOs.

Although the d-s hybridization gives rise to a notable $\mathrm{Pt}(6 \mathrm{~s})$ occupation in the natural population analysis (NPA), the NPA charge and population at the Pt center of $\mathbf{1}$ is comparable with those of well-known square-planar $\mathrm{Pt}(\mathrm{II})$ complexes and $\mathrm{PtCl}_{2}$ (a hypothetical but clear-cut example of a two-coordinate $\operatorname{Pt}(\mathrm{II})$ molecule) and differs notably from known $\operatorname{Pt}(\mathrm{I})$ and $\operatorname{Pt}(0)$ complexes, consistent with the Pt(II) oxidation-state assignment for $\mathbf{1}$ and $\mathbf{1}^{\prime}$ (cf. Table 2 for NPA charges and electron configurations at the metal center for a series of pertinent complexes). Our oxidation-state assignment is also confirmed by using the localized orbital bonding analysis (LOBA) method (Table 2), ${ }^{59}$ which accurately produces the chemically intuitive oxidation state for challenging systems with redox non-innocent ligands..$^{60,61}$ 
Table 2. NPA charges, electron configurations, and spin-densities at the Pt center, as well as metal oxidation-states (OS) assigned by a localized-orbital bonding analysis (LOBA), for a series of pertinent two-coordinate and square-planar $\operatorname{Pt}(\mathrm{II}), \operatorname{Pt}(\mathrm{I})$, and $\mathrm{Pt}(0)$ complexes ${ }^{a}$

\begin{tabular}{|c|c|c|c|c|c|c|c|}
\hline \multirow[t]{2}{*}{ Complex } & \multirow{2}{*}{$\begin{array}{l}\text { spin-state } \\
(\Delta \mathrm{E}, \mathrm{kJ} / \mathrm{mol})\end{array}$} & \multirow{2}{*}{$\begin{array}{l}d(\mathrm{Pt}-\mathrm{L}) \\
{[\AA]}\end{array}$} & \multirow{2}{*}{$\begin{array}{l}\text { NPA charge } \\
q(\mathrm{Pt})\end{array}$} & \multicolumn{2}{|c|}{$\begin{array}{l}\text { el. configuration } \\
\text { on } \mathrm{Pt}\end{array}$} & \multirow{2}{*}{$\begin{array}{l}\text { spin-density } \\
\rho(\mathrm{Pt})\end{array}$} & \multirow{2}{*}{$\begin{array}{l}\text { OS of Pt } \\
\text { (LOBA) }\end{array}$} \\
\hline & & & & $6 s$ & $5 \mathrm{~d}$ & & \\
\hline \multirow[t]{2}{*}{$\mathrm{Pt}\left(\mathrm{N}=\mathrm{C}^{\mathrm{t}} \mathrm{Bu}_{2}\right)_{2}(\mathbf{1})$} & $\mathrm{S}=0(0.0)$ & 1.803 & +0.433 & 0.96 & 8.59 & - & $\mathrm{Pt}(\mathrm{II})$ \\
\hline & $\mathrm{S}=1(75.2)^{b}$ & 1.856 & +0.276 & 1.00 & 8.74 & 0.55 & $\operatorname{Pt}(0)$ \\
\hline \multirow[t]{2}{*}{$\mathrm{PtCl}_{2}\left(D_{\infty \mathrm{h}}\right)$} & $\mathrm{S}=0(97.1)^{c}$ & 2.148 & +0.438 & 0.92 & 8.63 & - & $\mathrm{Pt}(\mathrm{II})$ \\
\hline & $\mathrm{S}=1(0.0)^{c}$ & 2.155 & +0.541 & 0.92 & 8.52 & 1.21 & $\operatorname{Pt}(\mathrm{II})$ \\
\hline $\mathrm{PtCl}_{2}\left(C_{2 \mathrm{v}}\right)$ & $\mathrm{S}=0(58.5)^{d}$ & 2.156 & +0.536 & 0.66 & 8.75 & - & $\operatorname{Pt}(\mathrm{II})$ \\
\hline$\left[\mathrm{Pt}\left(\mathrm{P}^{t} \mathrm{Bu}_{3}\right)_{2}\right]^{+},{ }^{3}$ & $\mathrm{~S}=1 / 2$ & 2.271 & +0.239 & 1.02 & 8.75 & 1.00 & $\operatorname{Pt}(\mathrm{I})$ \\
\hline $\left.\operatorname{Pt}\left(\mathrm{P}^{\mathrm{t}} \mathrm{Bu}\right)_{2}\right)_{2}{ }^{3}$ & $S=0$ & 2.267 & -0.490 & 0.89 & 9.59 & - & $\operatorname{Pt}(0)$ \\
\hline $\operatorname{Pt}(\mathrm{cAAC})_{2},{ }^{4}$ & $S=0$ & 1.975 & -0.203 & 1.00 & 9.19 & - & $\operatorname{Pt}(0)$ \\
\hline $\mathrm{Pt}(\mathrm{CNAr})_{2},{ }^{5}$ & $S=0$ & 1.899 & -0.162 & 1.01 & 9.16 & - & $\operatorname{Pt}(0)$ \\
\hline $\mathrm{Pt}(\mathrm{NHC})_{2}{ }^{6}$ & $\mathrm{~S}=0$ & 1.970 & -0.359 & 1.10 & 9.25 & - & $\operatorname{Pt}(0)$ \\
\hline \multirow[t]{2}{*}{ trans $-\mathrm{PtCl}_{2}\left(\mathrm{NH}_{3}\right)_{2}$} & $\mathrm{~S}=0$ & $2.035(\mathrm{Pt}-\mathrm{N})$ & +0.588 & 0.63 & 8.76 & - & $\mathrm{Pt}(\mathrm{II})$ \\
\hline & & $2.299(\mathrm{Pt}-\mathrm{Cl})$ & & & & & \\
\hline $\mathrm{Pt}\left(\mathrm{PPh}_{3}\right)_{4}$ & $\mathrm{~S}=0$ & 2.346 & +0.053 & 0.50 & 9.45 & - & $\operatorname{Pt}(0)$ \\
\hline
\end{tabular}

${ }^{a}$ PBE0-D3(BJ)/ECP/def2-TZVP results (see Computational details); ${ }^{b}$ Structure of 1 with an orthogonal arrangement of two ketimide ligands; ${ }^{c}$ Linear $\left(D_{\text {oh }}\right)$ structure of $\mathrm{PtCl}_{2}\left(\alpha=180^{\circ}\right){ }^{d}$ Bent $\left(C_{2 \mathrm{v}}\right)$ structure of $\mathrm{PtCl}_{2}\left(\alpha=115^{\circ}\right)$

Both $\mathbf{1}$ and $\mathbf{1}^{\prime}$ are computed to feature a high degree of $\mathrm{Pt}=\mathrm{N}$ multiple bond character, as revealed by a natural localized molecular orbital (NLMO) analysis and the computed QTAIM delocalization indices, DI(M-N) (Table 1), which is consistent with the short Pt-N bonds observed for 1 in the solid-state. The DI(M-N) integrates the electron density in the region between two atoms in question ( $\mathrm{M}$ and $\mathrm{N}$ ) and is closely related to the covalent bond order, reduced by bond polarity. For comparison, the $\mathrm{DI}(\mathrm{Pt}-\mathrm{N})$ values in cisplatin $\left(\right.$ cis- $\left.-\mathrm{PtCl}_{2}\left(\mathrm{NH}_{3}\right)_{2}\right)$ and transplatin (trans$\left.\mathrm{PtCl}_{2}\left(\mathrm{NH}_{3}\right)_{2}\right)$ are computed to be 0.768 and 0.810 , respectively, which are roughly a half that of $\mathbf{1}$. According to Adaptive Natural Density Partitioning (AdNDP) analysis, ${ }^{55}$ which is capable of 
identifying multicenter bonds, the Pt-N interactions of $\mathbf{1}$ (and $\mathbf{1}^{\prime}$ ) can be best described as a $\mathrm{Pt}=\mathrm{N}$ double bond with one $\sigma(\mathrm{Pt}-\mathrm{N})$ and one "in-plane" $\pi-(\mathrm{Pt}-\mathrm{N})$ component on each side of the molecule (Figure 5). These interactions are further strengthened by a delocalized five-center, two-electron (5c2e) bond across the entire $\mathrm{C}=\mathrm{N}=\mathrm{Pt}=\mathrm{N}=\mathrm{C}$ fragment, which corresponds to the Pt-N $\pi$ backdonation from the "out-of-plane" $\operatorname{Pt}\left(5 \mathrm{~d}_{\mathrm{xz}}\right)$ orbital into both $\pi^{*}(\mathrm{C}=\mathrm{N})$ antibonding MOs of the ketimide ligands. In the NLMO analysis, this interaction is approximated by a three-center twoelectron $\pi(\mathrm{N} \leftarrow \mathrm{M} \rightarrow \mathrm{N})$ bonding (Table 1 and Figure S20) and becomes more covalent, along with the $\sigma(\mathrm{M} \leftarrow \mathrm{N})$ component, on moving down group 10, which can be attributed to the more diffuse valence d-orbitals of the heavier metals (see also Table S4 for results of EDA analysis, which provide similar trends). The lack of an analogous $\pi$-backdonation interaction in the group 10 $\mathrm{M}\left(\mathrm{N}^{t} \mathrm{Bu}_{2}\right)_{2}$ bis(amide) series is likely responsible for their longer $\mathrm{M}-\mathrm{N}$ bonds, as compared to ketimides (Table S3). For instance, the Pt-N bond-length in the hypothetical bis(amide) $\mathrm{Pt}\left(\mathrm{N}^{t} \mathrm{Bu}_{2}\right)_{2}$ is computed to be $1.892 \AA$, which is $0.09 \AA$ longer than that of $\mathbf{1}$.

As discussed above, the experimental structure of $\mathbf{1}$ exhibits a co-planar (eclipsed) arrangement of its ketimide ligands. We therefore explored computationally the alternative "allene-like" geometry wherein the ketimide ligands feature a staggered conformation. The structure of $\mathbf{1}$ with a staggered arrangement of the two ketimide ligands is computed to have a triplet ground-state $(S=1)$ and is energetically disfavored by $75.2 \mathrm{~kJ} / \mathrm{mol}$ in comparison to the experimentally-observed co-planar structure featuring a singlet ground-state (Tables 2 and S5). The energetic preference of the coplanar configuration permits the maximum constructive overlap between the $\pi$-symmetry orbitals on the ligand and the relevant $\mathrm{Pt}(5 \mathrm{~d})$ orbitals. Specifically, a p-orbital from each nitrogen interacts with the "in-plane" $5 d_{y z}$ orbital and a $\pi^{*}(\mathrm{C}=\mathrm{N})$ orbital from each ligand interacts with the "out-ofplane" $5 \mathrm{~d}_{\mathrm{xz}}$ orbital (Figure S23). In the structure with the orthogonal configuration, however, the 
two ketimide ligands must interact individually with the Pt center, via two different Pt(5d) orbitals. As a result, the two orthogonal $\mathrm{N}(2 \mathrm{p})$ orbitals cannot be involved in $\pi$-bonding; instead they are each occupied by an unpaired electron (cf. Figure S23 and Table S5 in SI for NLMO analysis and corresponding Lewis structures). Although these unpaired electrons are delocalized over the Pt and $\mathrm{N}$ atoms (cf. Figure S24 for the spin-density distribution), the metal center in the structure of 1 with an orthogonal arrangement of ketimide ligands is best characterized as a $\operatorname{Pt}(0)$ complex with two $\sigma(\mathrm{Pt} \leftarrow \mathrm{N})$ bonding and two $\pi(\mathrm{Pt} \rightarrow \mathrm{N})$ backbonding interactions. This is also reflected in the reduced atomic charge at the Pt center in contrast to the experimentally observed co-planar structure of $1(S=0)$, with its clear $\operatorname{Pt}(\mathrm{II})$ character (Table 2).

\section{Summary}

We have prepared and characterized the linear $\mathrm{Pt}(\mathrm{II})$ complex, $\mathrm{Pt}\left(\mathrm{N}=\mathrm{C}^{t} \mathrm{Bu}_{2}\right)_{2}$ (1), expanding the scope of $\mathrm{Pt}(\mathrm{II})$ coordination chemistry beyond the more common square planar and T-shaped geometries. While many two-coordinate $\mathrm{Pt}(0)$ and $\mathrm{Pt}(\mathrm{I})$ complexes are known, ${ }^{2-6}$ complex $\mathbf{1}$ is the first two-coordinate Pt(II) complex to be reported. ${ }^{1}$ Its unusual coordination geometry can be rationalized by its exceptionally covalent $\mathrm{M}-\mathrm{N}$ interactions, a consequence of the strong $\pi$-donor and $\pi$-acceptor properties of the linear ketimide ligand, as revealed by a detailed computational DFT analysis. These interactions result in short, highly covalent Pt-N bonds, which stabilize this formally unsaturated, $16 \mathrm{e}^{-}$species. This covalency is also evident in its highly deshielded ${ }^{195} \mathrm{Pt}$ chemical shift and large ${ }^{195} \mathrm{Pt}-{ }^{14} \mathrm{~N}$ nuclear spin-spin coupling constant.

For comparison, several two-coordinate $\mathrm{Ni}(\mathrm{II})$ complexes, such as $\left[\mathrm{Ni}\left\{\mathrm{N}(\mathrm{H}) \mathrm{Ar}^{\mathrm{iPr} 6}\right\}_{2}\right]\left(\operatorname{Ar}^{\mathrm{iPr} 6}=\right.$ $\left.\mathrm{C}_{6} \mathrm{H}_{3}-2,6\left(\mathrm{C}_{6} \mathrm{H}_{2}-2,4,6-{ }^{i} \mathrm{Pr}_{3}\right)_{2}\right),{ }^{62}$ are also known, but these tend to be paramagnetic, with high-spin $\mathrm{d}^{8}$ configurations at the Ni center. This change in the electronic ground-state is caused by two 
factors: first, the greater spatial extent of the $5 \mathrm{~d}$ vs. $3 \mathrm{~d}$ orbitals, and thus their better overlap with donor atoms on the ligands (i.e., larger M-L bond covalency); and, second, the strong $\pi$-donating and $\pi$-accepting properties of the linear ketimide ligand, which produces a larger crystal field than that provided by an amide ligand.

The unusual electronic properties imparted to Pt suggest that other linear $\left[\mathrm{M}(\text { ketimide })_{2}\right]^{\mathrm{n}+}$ complexes $(\mathrm{M}=$ transition metal or lanthanide) would also feature interesting electronic structures and could potentially possess unique magnetic properties. The generation of species of this type will likely require the use of substantially bulkier ketimide ligands, by analogy to the bulky alkyl, aryl, and amido ligands previously used to stabilize two-coordinate transition metal complexes; ${ }^{1,}$ 9, 12, 62 however, because of the relatively straightforward synthesis of the ketimide fragment, this should be easy to achieve.

\section{ASSOCIATED CONTENT}

Experimental, computational, and crystallographic details (as CIF files) for complexes 1 - 4. This material is available free of charge via the Internet at http://pubs.acs.org.

\section{AUTHOR INFORMATION}

\section{Corresponding Authors}

*hayton@chem.ucsb.edu

*peter.hrobarik@uniba.sk 


\section{ACKNOWLEDGMENT}

This work was supported by the National Science Foundation (CHE 1764345) and the Slovak Grant Agencies VEGA (grant Nos. 1/0507/17 and 1/0712/18) and APVV (grant No. APVV-170324). NMR spectra were collected on instruments supported by an NIH Shared Instrumentation Grant (SIG, 1S10OD012077-01A1). ESI mass spectra were acquired at the MRL Shared Experimental Facilities, supported by the MRSEC Program of the NSF under Award No. DMR 1720256 and a member of the NSF-funded Materials Research Facilities Network. A. W. C. thanks the Mellichamp Academic Initiative in Sustainability at UCSB for a summer fellowship. D. N. thanks the MRL for a PREM summer fellowship. Calculations were performed using the supercomputing infrastructure acquired in projects ITMS 26230120002 and 26210120002 supported by the Research \& Development Operational Programme funded by the ERDF. P. H. also acknowledges financial support from the European Union's Horizon 2020 research and innovation program under the Marie Skłodowska-Curie Grant No. 752285. We thank Dr. A. Almássy (Comenius University) for his kind assistance with NMR sample preparation and Prof. Joshua Telser (Roosevelt University) for helpful comments.

\section{REFERENCES}

1. Power, P. P., Stable Two-Coordinate, Open-Shell $\left(\mathrm{d}^{1}-\mathrm{d}^{9}\right)$ Transition Metal Complexes. Chem. Rev. 2012, 112, 3482-3507.

2. Immirzi, A.; Musco, A.; Zambelli, P.; Carturan, G., Nucleophilic attack on $\{(\pi-$ allyl $\left.) \mathrm{Pt}\left[\mathrm{P}\left(\mathrm{C}_{6} \mathrm{H}_{11}\right)_{3}\right]_{2}\right\} \mathrm{PF}_{6}$. Preparation and $\mathrm{x}$-ray structure of $\mathrm{Pt}\left[\mathrm{P}\left(\mathrm{C}_{6} \mathrm{H}_{11}\right)_{3}\right]_{2}$. Inorg. Chim. Acta 1975, 13, L13-L14.

3. MacInnis, M. C.; DeMott, J. C.; Zolnhofer, E. M.; Zhou, J.; Meyer, K.; Hughes, R. P.; Ozerov, O. V., Cationic Two-Coordinate Complexes of $\mathrm{Pd}(\mathrm{I})$ and $\mathrm{Pt}(\mathrm{I})$ Have Longer Metal-Ligand Bonds Than Their Neutral Counterparts. Chem 2016, 1, 902-920.

4. Roy, S.; Mondal, K. C.; Meyer, J.; Niepötter, B.; Köhler, C.; Herbst-Irmer, R.; Stalke, D.; Dittrich, B.; Andrada, D. M.; Frenking, G.; Roesky, H. W., Synthesis, Characterization, and Theoretical Investigation of Two-Coordinate Palladium(0) and Platinum(0) Complexes Utilizing $\pi$-Accepting Carbenes. Chem. Eur. J. 2015, 21, 9312-9318. 
5. $\quad$ Barnett, B. R.; Moore, C. E.; Rheingold, A. L.; Figueroa, J. S., Cooperative Transition Metal/Lewis Acid Bond-Activation Reactions by a Bidentate (Boryl)iminomethane Complex: A Significant Metal-Borane Interaction Promoted by a Small Bite-Angle LZ Chelate. J. Am. Chem. Soc. 2014, 136, 10262-10265.

6. Bauer, J.; Braunschweig, H.; Brenner, P.; Kraft, K.; Radacki, K.; Schwab, K., LateTransition-Metal Complexes as Tunable Lewis Bases. Chem. Eur. J. 2010, 16, 11985-11992.

7. Yang, J.; Tilley, T. D., Efficient Hydrosilylation of Carbonyl Compounds with the Simple Amide Catalyst [Fe $\left.\left\{\mathrm{N}\left(\mathrm{SiMe}_{3}\right)_{2}\right\}_{2}\right]$. Angew. Chem. Int. Ed. 2010, 49, 10186-10188.

8. Gieshoff, T. N.; Chakraborty, U.; Villa, M.; Jacobi von Wangelin, A., Alkene Hydrogenations by Soluble Iron Nanocluster Catalysts. Angew. Chem. Int. Ed. 2017, 56, 35853589 .

9. Zadrozny, J. M.; Atanasov, M.; Bryan, A. M.; Lin, C.-Y.; Rekken, B. D.; Power, P. P.; Neese, F.; Long, J. R., Slow magnetization dynamics in a series of two-coordinate iron(ii) complexes. Chem. Sci. 2013, 4, 125-138.

10. Atanasov, M.; Zadrozny, J. M.; Long, J. R.; Neese, F., A theoretical analysis of chemical bonding, vibronic coupling, and magnetic anisotropy in linear iron(ii) complexes with singlemolecule magnet behavior. Chem. Sci. 2013, 4, 139-156.

11. Bunting, P. C.; Atanasov, M.; Damgaard-Møller, E.; Perfetti, M.; Crassee, I.; Orlita, M.; Overgaard, J.; van Slageren, J.; Neese, F.; Long, J. R., A linear cobalt(II) complex with maximal orbital angular momentum from a non-Aufbau ground state. Science 2018, 362, eaat7319. 12. Reiff, W. M.; Schulz, C. E.; Whangbo, M.-H.; Seo, J. I.; Lee, Y. S.; Potratz, G. R.; Spicer, C. W.; Girolami, G. S., Consequences of a Linear Two-Coordinate Geometry for the Orbital Magnetism and Jahn-Teller Distortion Behavior of the High Spin Iron(II) Complex $\mathrm{Fe}\left[\mathrm{N}(t-\mathrm{Bu})_{2}\right]_{2}$. J. Am. Chem. Soc. 2009, 131, 404-405.

13. Zadrozny, J. M.; Xiao, D. J.; Long, J. R.; Atanasov, M.; Neese, F.; Grandjean, F.; Long, G. J., Mössbauer Spectroscopy as a Probe of Magnetization Dynamics in the Linear Iron(I) and Iron(II) Complexes $\left[\mathrm{Fe}\left(\mathrm{C}\left(\mathrm{SiMe}_{3}\right)_{3}\right)_{2}\right]^{1-/ 0}$. Inorg. Chem. 2013, 52, 13123-13131.

14. Zadrozny, J. M.; Xiao, D. J.; Atanasov, M.; Long, G. J.; Grandjean, F.; Neese, F.; Long, J. R., Magnetic blocking in a linear iron(I) complex. Nat. Chem. 2013, 5, 577-581.

15. Guo, F.-S.; Day, B. M.; Chen, Y.-C.; Tong, M.-L.; Mansikkamäki, A.; Layfield, R. A., A Dysprosium Metallocene Single-Molecule Magnet Functioning at the Axial Limit. Angew. Chem. Int. Ed. 2017, 56, 11445-11449.

16. Goodwin, C. A. P.; Ortu, F.; Reta, D.; Chilton, N. F.; Mills, D. P., Molecular magnetic hysteresis at 60 kelvin in dysprosocenium. Nature 2017, 548, 439.

17. Guo, F.-S.; Day, B. M.; Chen, Y.-C.; Tong, M.-L.; Mansikkamäki, A.; Layfield, R. A., Magnetic hysteresis up to 80 kelvin in a dysprosium metallocene single-molecule magnet. Science 2018, 362, 1400-1403.

18. Ding, Y.-S.; Chilton, N. F.; Winpenny, R. E. P.; Zheng, Y.-Z., On Approaching the Limit of Molecular Magnetic Anisotropy: A Near-Perfect Pentagonal Bipyramidal Dysprosium(III) Single-Molecule Magnet. Angew. Chem. Int. Ed. 2016, 55, 16071-16074.

19. Clegg, W.; Snaith, R.; Shearer, H. M. M.; Wade, K.; Whitehead, G., Azomethine derivatives. Part 20. Crystal and molecular structures of the lithioketimine $\left[\left\{\mathrm{Li}\left(\mathrm{N}=\mathrm{CBu}_{2}^{\mathrm{t}}\right)\right\}_{6}\right]$ and lithioguanidine $\left[\left\{\mathrm{Li}\left[\mathrm{N}=\mathrm{C}\left(\mathrm{NMe}_{2}\right)_{2}\right]\right\} 6\right.$; ; electron-deficient bridging of $\mathrm{Li}_{3}$ triangles by methyleneamino-nitrogen atoms. J. Chem. Soc., Dalton Trans. 1983, 1309-1317.

20. Chan, L.-H.; Rochow, E. G., Syntheses and ultraviolet spectra of N-organosilyl ketimines. J. Organomet. Chem. 1967, 9, 231-250. 
21. Barr, D.; Clegg, W.; Mulvey, R. E.; Snaith, R.; Wade, K., Bonding implications of interatomic distances and ligand orientations in the iminolithium hexamers $\left[\mathrm{LiN}=\mathrm{C}(\mathrm{Ph}) \mathrm{Bu}^{\mathrm{t}}\right]_{6}$ and $\left[\mathrm{LiN}=\mathrm{C}(\mathrm{Ph}) \mathrm{NMe}_{2}\right]_{6}$ : a stacked-ring approach to these and related oligomeric organolithium systems. J. Chem. Soc., Chem. Commun. 1986, 295-297.

22. Avent, A. G.; Antolini, F.; Hitchcock, P. B.; Khvostov, A. V.; Lappert, M. F.; Protchenko, A. V., Reactions between a sodium amide $\mathrm{Na}\left[\mathrm{N}\left(\mathrm{SiMe}_{3}\right) \mathrm{R}^{1}\right]\left(\mathrm{R}^{1}=\mathrm{SiMe}_{3}, \mathrm{SiMe}_{2} \mathrm{Ph}\right.$ or $\left.\mathrm{Bu}^{t}\right)$ and a cyanoalkane $\mathrm{RCN}\left(\mathrm{R}=\mathrm{Ad}\right.$ or $\left.\mathrm{Bu}^{t}\right)$. Dalton Trans. 2006, 919-927.

23. Nam, W., High-Valent Iron(IV) Oxo Complexes of Heme and Non-Heme Ligands in Oxygenation Reactions. Acc. Chem. Res. 2007, 40, 522-531.

24. Lewis, R. A.; Wu, G.; Hayton, T. W., Synthesis and Characterization of an Iron(IV) Ketimide Complex. J. Am. Chem. Soc. 2010, 132, 12814-12816.

25. Lewis, R. A.; George, S. P.; Chapovetsky, A.; Wu, G.; Figueroa, J. S.; Hayton, T. W., Synthesis of a cobalt(iv) ketimide with a squashed tetrahedral geometry. Chem. Commun. 2013, 49, 2888-2890.

26. Damon, P. L.; Liss, C. J.; Lewis, R. A.; Morochnik, S.; Szpunar, D. E.; Telser, J.; Hayton, T. W., Quantifying the Electron Donor and Acceptor Abilities of the Ketimide Ligands in $\mathrm{M}\left(\mathrm{N}=\mathrm{C}^{t} \mathrm{Bu}_{2}\right)_{4}(\mathrm{M}=\mathrm{V}, \mathrm{Nb}, \mathrm{Ta})$. Inorg. Chem. 2015, 54, 10081-10095.

27. Lewis, R. A.; Smiles, D. E.; Darmon, J. M.; Stieber, S. C. E.; Wu, G.; Hayton, T. W., Reactivity and Mössbauer Spectroscopic Characterization of an Fe(IV) Ketimide Complex and Reinvestigation of an Fe(IV) Norbornyl Complex. Inorg. Chem. 2013, 52, 8218-8227.

28. Lewis, R. A.; Wu, G.; Hayton, T. W., Stabilizing High-Valent Metal Ions with a Ketimide Ligand Set: Synthesis of $\mathrm{Mn}\left(\mathrm{N}=\mathrm{C}^{\mathrm{t}} \mathrm{Bu}_{2}\right)_{4}$. Inorg. Chem. 2011, 50, 4660-4668.

29. Soriaga, R. A. D.; Nguyen, J. M.; Albright, T. A.; Hoffman, D. M., Diamagnetic Group 6 Tetrakis(di-tert-butylketimido)metal(IV) Complexes. J. Am. Chem. Soc. 2010, 132, 1801418016.

30. Martins, A. M.; Marques, M. M.; Ascenso, J. R.; Dias, A. R.; Duarte, M. T.; Fernandes, A. C.; Fernandes, S.; Ferreira, M. J.; Matos, I.; Conceição Oliveira, M.; Rodrigues, S. S.; Wilson, C., Titanium and zirconium ketimide complexes: synthesis and ethylene polymerisation catalysis. J. Organomet. Chem. 2005, 690, 874-884.

31. Soriaga, R. A. D.; Javed, S.; Hoffman, D. M., Synthesis of Copper(I) Complexes with Ketimide and Hydrazide Ligands. J. Cluster Sci. 2010, 21, 567-575.

32. Seaman, L. A.; Wu, G.; Edelstein, N. M.; Lukens, W. W.; Magnani, N.; Hayton, T. W., Probing the $5 f$ Orbital Contribution to the Bonding in a $\mathrm{U}(\mathrm{V})$ Ketimide Complex. J. Am. Chem. Soc. 2012, 134, 4931-4940.

33. Shearer, H. M. M.; Snaith, R.; Sowerby, J. D.; Wade, K., Lithium tetrakis(di-tbutylmethyleneamino)aluminate. J. Chem. Soc., Chem. Commun. 1971, 1275-1276.

34. Pattison, I.; Wade, K.; Wyatt, B. K., Azomethine derivatives. Part V. Reactions between organolithium compounds and diphenylketimine, some cyanides, and NNN'N'tetramethylguanidine. J. Chem. Soc. A 1968, 837-842.

35. Assefa, M. K.; Sergentu, D.-C.; Seaman, L. A.; Wu, G.; Autschbach, J.; Hayton, T. W., Synthesis, Characterization, and Electrochemistry of the Homoleptic f Element Ketimide Complexes $[\mathrm{Li}]_{2}\left[\mathrm{M}\left(\mathrm{N}=\mathrm{C}^{\mathrm{t}} \mathrm{BuPh}\right)_{6}\right](\mathrm{M}=\mathrm{Ce}, \mathrm{Th})$. Inorg. Chem. 2019, 58, 12654-12661.

36. Crabtree, R. H., The Organometallic Chemistry of the Transition Metals. 5th ed.; Wiley: 2011.

37. Cambridge Structural Database, version 5.36; Cambridge Crystallographic Data Centre: 2015. 
38. Eadie, D. T.; Pidcock, A.; Stobart, S. R.; Brennan, E. T.; Cameron, T. S., Amidocomplexes of platinum(II). An X-ray crystal structure determination of cis-[PtCl( $\left.\left.\mathrm{NPh}_{2}\right)\left(\mathrm{PEt}_{3}\right)_{2}\right]$. Inorg. Chim. Acta 1982, 65, L111-L112.

39. Bryndza, H. E.; Fultz, W. C.; Tam, W., Preparation and chemistry of novel platinum(II) amide complexes containing $\beta$-hydrogens. Organometallics 1985, 4, 939-940.

40. Cowan, R. L.; Trogler, W. C., Syntheses, reactions, and molecular structures of transhydrido(phenylamido)bis(triethylphosphine)platinum(II) and transhydridophenoxobis(triethylphosphine)platinum(II). J. Am. Chem. Soc. 1989, 111, 4750-4761.

41. Sundquist, W. I.; Bancroft, D. P.; Lippard, S. J., Synthesis, characterization, and biological activity of cis-diammineplatinum(II) complexes of the DNA intercalators 9-aminoacridine and chloroquine. J. Am. Chem. Soc. 1990, 112, 1590-1596.

42. Cucciolito, M. E.; De Felice, V.; Giordano, F.; Orabona, I.; Ruffo, F., Nucleophilic Attack of Carbanions on Cationic Platinum(II) Nitrile Complexes Affording Stable $\eta^{1}$-Imine Enol and $\eta^{1}$ Enamine Coordinated Fragments. Eur. J. Inorg. Chem. 2001, 2001, 3095-3100.

43. Lewis, R. A.; Morochnik, S.; Chapovetsky, A.; Wu, G.; Hayton, T. W., Synthesis and Characterization of $\left[\mathrm{M}_{2}\left(\mathrm{~N}=\mathrm{C}^{\mathrm{t}} \mathrm{Bu}_{2}\right)_{5}\right]^{-}(\mathrm{M}=\mathrm{Mn}, \mathrm{Fe}, \mathrm{Co})$ : Metal Ketimide Complexes with Strong Metal-Metal Interactions. Angew. Chem. Int. Ed. 2012, 51, 12772-12775.

44. Park, S.; Roundhill, D. M.; Rheingold, A. L., New monomeric and binuclear hydride- and alkyl-substituted platinum(II) complexes having unsubstituted terminal or bridging amide ligands. Inorg. Chem. 1987, 26, 3972-3974.

45. Henderson, W.; Oliver, A. G., An investigation of the mixed-bridge dinuclear complex $\left[\mathrm{Pt}_{2}(\mu-\mathrm{S})\left(\mu-\mathrm{NH}_{2}\right)\left(\mathrm{PPh}_{3}\right)_{4}\right]^{+}$. Inorg. Chim. Acta 2014, 416, 49-56.

46. de C. T. Carrondo, M. A. A. F.; Skapski, A. C., X-Ray crystal structure of tetrameric platinum(II) acetate: a square-cluster complex with short $\mathrm{Pt}-\mathrm{Pt}$ bonds and octahedral co-ordination geometry. J. Chem. Soc., Chem. Commun. 1976, 410-411.

47. Simms, B. L.; Shang, M.; Lu, J.; Youngs, W. J.; Ibers, J. A., Preferential activation of a tert-butyl group over a cyclopropyl group in the intramolecular reaction of trans-dichlorobis(ditert-butylcyclopropylphosphine)platinum(II) to form a platinaphosphacyclobutane. Synthesis and structure of $\mathrm{PtCl}_{2}\left[\mathrm{P}(\text { tert-Bu})_{2} \text { cyclopropyl }\right]_{2}$ and its derivatives. Organometallics 1987, 6, 11181126.

48. Troadec, T.; Tan, S.-y.; Wedge, C. J.; Rourke, J. P.; Unwin, P. R.; Chaplin, A. B., OneElectron Oxidation of $\left[\mathrm{M}\left(\mathrm{P}^{\mathrm{t}} \mathrm{Bu}_{3}\right)_{2}\right](\mathrm{M}=\mathrm{Pd}, \mathrm{Pt})$ : Isolation of Monomeric $\left[\mathrm{Pd}\left(\mathrm{P}^{\mathrm{t}} \mathrm{Bu}_{3}\right)_{2}\right]^{+}$and RedoxPromoted C-H Bond Cyclometalation. Angew. Chem. Int. Ed. 2016, 55, 3754-3757.

49. Crosby, S. H.; Clarkson, G. J.; Rourke, J. P., Reactions of a Platinum(II) Agostic Complex: Decyclometalation, Dicyclometalation, and Solvent-Switchable Formation of a Rollover Complex. Organometallics 2011, 30, 3603-3609.

50. Roselló-Merino, M.; Rama, R. J.; Díez, J.; Conejero, S., Catalytic dehydrocoupling of amine-boranes and amines into diaminoboranes: isolation of a Pt(ii), Shimoi-type, $\eta^{1}$-BH complex. Chem. Commun. 2016, 52, 8389-8392.

51. The 2c-ZORA(SO)/PBE/QZ4P method is benchmarked for a wide series of Pt(II) complexes characterized in non-aqueous deuterated solvents, giving an excellent agreement with experimental ${ }^{195} \mathrm{Pt}$ NMR shifts $\left(\mathrm{R}^{2}=0.979\right.$; RMSD $=183.5 \mathrm{ppm}$; see Table $\mathrm{S} 7$ and Figure $\mathrm{S} 25$ in $\mathrm{SI})$. For related DFT study on ${ }^{195} \mathrm{Pt}$ NMR shifts and importance of relativistic effects, see also: a) Truflandier, L. A.; Sutter, K.; Autschbach, J. Inorg. Chem. 2011, 50, 1723-1732; b) Greif, A. H.; Hrobárik, P.; Hrobáriková, V.; Arbuznikov, A. V.; Autschbach, J.; Kaupp, M. Inorg. Chem. 2015, 54, 7199-7208; c) Hrobárik, P.; Hrobáriková, V.; Meier, F.; Repiský, M.; Komorovský, S.; Kaupp, 
M. J. Phys. Chem. A 2011, 115, 5654-5659; d) Hrobárik, P.; Hrobáriková, V.; Greif, A.; Kaupp, M. Angew. Chem. Int. Ed. 2012, 51, 10884-10888; e) Greif, A. H.; Hrobárik, P.; Kaupp, M. Chem. - Eur. J. 2017, 23, 9790-9803.

52. This can be likely attributed to the faster relaxation rate due to dipole-dipole interactions, giving rise to substantial NMR peaks broadening.

53. Autschbach, J., Orbitals: Some Fiction and Some Facts. J. Chem. Ed. 2012, 89, 1032-1040.

54. Reed, A. E.; Weinhold, F., Natural localized molecular orbitals. J. Chem. Phys. 1985, 83, 1736-1740.

55. Zubarev, D. Y.; Boldyrev, A. I., Developing paradigms of chemical bonding: adaptive natural density partitioning. Phys Chem Chem Phys 2008, 10, 5207-5217.

56. Krishnamurthy, R.; Schaap, W. B., Computing ligand field potentials and relative energies of d orbitals: A simple general approach. J. Chem. Ed. 1969, 46, 799.

57. Wang, S. G.; Schwarz, W. H. E., Density functional study of first row transition metal dihalides. J. Chem. Phys. 1998, 109, 7252-7262.

58. We also note that a comparable $\mathrm{MO}$ picture is obtained for $\mathrm{PtCl}_{2}$ in its singlet state (Figure S19 in SI); however, the ligand-field of the chlorides is not very strong and this molecule is predicted to possess a triplet ground-state (cf. Table 2).

59. Thom, A. J. W.; Sundstrom, E. J.; Head-Gordon, M., LOBA: a localized orbital bonding analysis to calculate oxidation states, with application to a model water oxidation catalyst. Phys. Chem. Chem. Phys. 2009, 11, 11297-11304.

60. For instance, according to the LOBA analysis, Allred's $[\mathrm{Hg}(\mathrm{cyclam})]^{3+}$ is correctly assigned as a $\mathrm{Hg}(\mathrm{II})$ complex with an oxidized amine ligand, which is consistent with the measured EPR spectroscopic parameters. See: Hrobárik, P. , Kaupp, M. and Riedel, S. Angew. Chem. Int. Ed., 2008, 47, 8631-8633

61. Deming, R. L.; Allred, A. L.; Dahl, A. R.; Herlinger, A. W.; Kestner, M. O., Tripositive mercury. Low temperature electrochemical oxidation of 1,4,8,11tetraazacyclotetradecanemercury(II) tetrafluoroborate. J. Am. Chem. Soc. 1976, 98, 4132-4137.

62. Bryan, A. M.; Merrill, W. A.; Reiff, W. M.; Fettinger, J. C.; Power, P. P., Synthesis, Structural, and Magnetic Characterization of Linear and Bent Geometry Cobalt(II) and Nickel(II) Amido Complexes: Evidence of Very Large Spin-Orbit Coupling Effects in Rigorously Linear Coordinated $\mathrm{Co}^{2+}$. Inorg. Chem. 2012, 51, 3366-3373. 


\section{TOC SYNOPSIS}

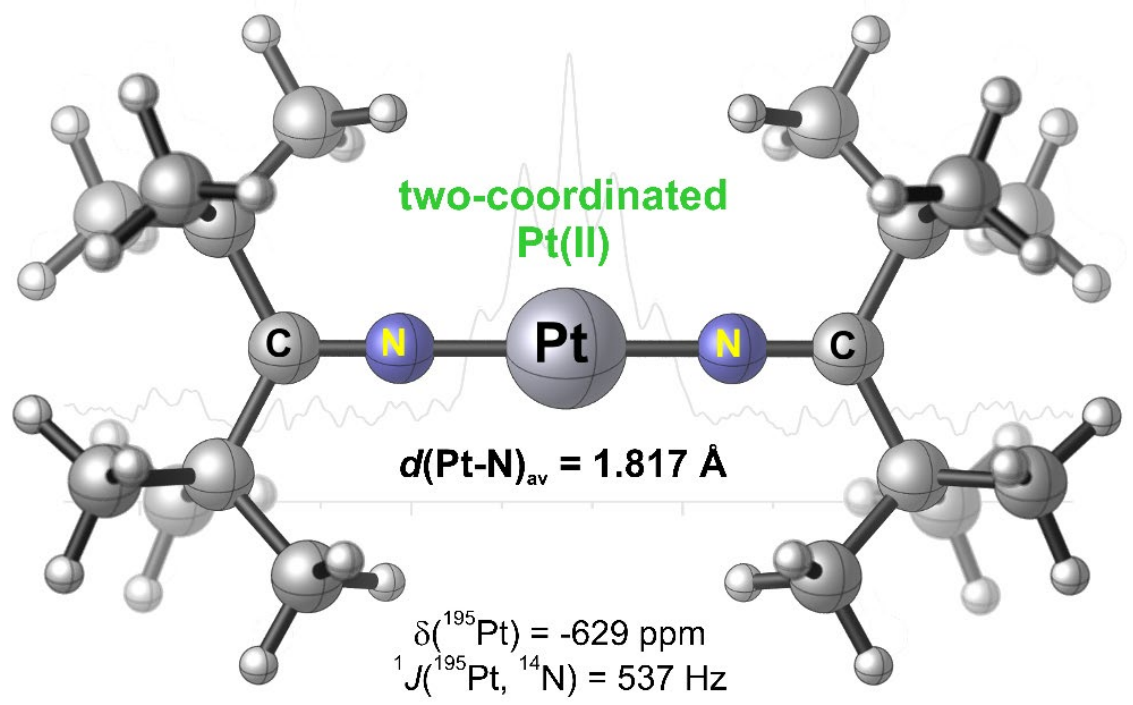

$\mathrm{Pt}\left(\mathrm{N}=\mathrm{C}^{\mathrm{t}} \mathrm{Bu}_{2}\right)_{2}$ represents the first linear $\mathrm{Pt}(\mathrm{II})$ complex to be reported, expanding the scope of Pt(II) coordination chemistry beyond the more common square planar and T-shaped geometries. 